\title{
Tannin extracts on quality of fresh cut crisp leaf lettuce
}

\section{Extratos de taninos na qualidade de alface crespa minimamente processada}

\author{
Tâmmila Venzke Klug ${ }^{I^{*}}$ Moises Jardim Segaspini ${ }^{I}$ Júnia Capua de Lima Novello II, III \\ Amanda Bianchini Moresco ${ }^{I}$ Ana Raisa Paiva ${ }^{I V}$ Alessandro de Oliveira Rios ${ }^{\text {IV }}$ \\ Eduardo Cesar Tondo ${ }^{\text {III }}$ Renar João Bender ${ }^{\mathrm{I}}$
}

\section{ABSTRACT}

In the present study, tannin extracts (rinsed or not) were compared to the use of sodium hypochlorite and tap water on fresh cut crisp leaf lettuce stored under modified atmosphere packaging. Effects of these sanitizers on total color difference and microbial levels of the product after sanitization and storage for 9 days at $3^{\circ} \mathrm{C}$ were evaluated. Performance of rinsed $S M^{\circledR}$ tannin extract was comparable to the results of chlorine solution for all the analyzed parameters and; furthermore, that extract presented a high reduction in the initial bacterial count of minimally processed lettuce. However, storage of tannin extracts, did not impart better outcomes than the use of tap water. Therefore, the tannin extract storage $S M^{\circledR}$ could be used in washing water to reduce the initial microbiological load, avoiding cross contamination in vegetables minimally processed.

Key words: fresh cut lettuce, tannin extracts, postharvest storage, Acacia mearnsii De Wild.

RESUMO

Extratos de taninos (com e sem enxague) foram comparados com o uso de hipoclorito de sódio e água em alface crespa minimamente processada, sob atmosfera modificada. Foram avaliadas diferença total de cor e análises microbiológicas após a sanitização e durante o armazenamento dos produtos (9 dias à $3^{\circ} \mathrm{C}$ ). $O$ extrato de tanino $S M^{\circledR}$ com enxague apresentou resultados semelhantes aos da solução de cloro para todos os parâmetros analisados e, além disso, apresentou uma elevada redução da contagem inicial microbiológica de alface minimamente processada. No entanto, durante o armazenamento, $S M^{\circledR}$ não apresentou melhores resultados do que o uso de água.
Portanto, $S M^{\circledR}$ poderia ser utilizado na desinfecção da água de lavagem das alfaces, reduzindo a microbiota inicial e, assim, impedir a contaminação cruzada durante o processamento mínimo de vegetais.

Palavras-chave: alface minimamente processada, extratos de taninos, conservação pós-colheita, Acacia mearnsii De Wild.

\section{INTRODUCTION}

Lettuce (Lactuca sativa L.) is the most consumed leafy vegetable in Brazil. Lettuce accounts for approximately $40 \%$ of the total sales volume of fresh produce supply companies (SALA \& COSTA, 2012). Nonetheless, concurrent to the consumption of fresh vegetables is the concern regarding microbiological safety of these products, i. e., potential contamination sources as a result of the presence of pathogenic bacteria (ANDERSON et al., 2011).

Sanitation techniques applied to minimally processed products target microbiological safety and prolong shelf life. Sodium hypochlorite is the most common sanitizer due to its low cost. However, sodium hypochlorite use might be questioned because of the likelihood of trihalomethane synthesis

'Laboratório de Pós-colheita, Universidade Federal do Rio Grande do Sul (UFRGS), Av. Bento Gonçalves, 7712, 91540-000, Porto Alegre, RS, Brasil. E-mail: tammilaklug@gmail.com. ${ }^{*}$ Corresponding author.

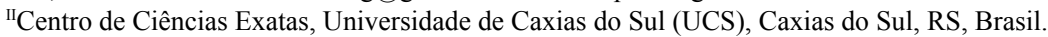

III Laboratório de Microbiologia e Controle de Alimentos, Instituto de Ciência e Tecnologia de Alimentos (ICTA), Universidade Federal do Rio Grande do Sul (UFRGS), Porto Alegre, RS, Brasil.

${ }^{\text {IV }}$ Laboratório de Compostos Bioativos, Instituto de Ciência e Tecnologia de Alimentos (ICTA), Universidade Federal do Rio Grande do Sul (UFRGS), Porto Alegre, RS, Brasil. 
resulting from contacts with organic matter (ÖLMEZ \& KRETZSCHMAR, 2009). The presence of organic matter might promote the formation of haloacetic acids, chloroform $\left(\mathrm{CHCl}_{3}\right)$ or other trihalomethanes (THM), all of which are known to be harmful to human health (ARTÉS et al., 2009). In countries such as Germany, Denmark and Belgium, the use of chlorine as sanitizer is already banned (ARTÉS \& ALLENDE, 2005).

Great interest has evolved in recent years for sanitization agents/methods to provide low energy demand and competitive costs, being environment friendly, and ensuring the microbiological safety and nutritional and sensorial quality of food. (SÃO JOSÉ et al., 2014). In such context, tannins have drawn attention due to biological and physiological properties (CHUNG et al., 2008). Several studies indicated in vitro bacteriostatic activity of tannin extracts against Escherichia coli, Salmonella typhi and Staphylococcus aureus (ARIAS et al., 2004; VORAVUTHIKUNCHAI et al., 2004; HERNÁNDEZ et al., 2009). These studies entrust the scientific basis to support tannin extracts treatments as sanitizers for lettuce. Furthermore, tannin extracts are rather inexpensive, easily formulated and ecofriendly.

Evaluation of tannin extracts as disinfectants of minimally processed lettuce constitutes a novel research area, yet it is important to evaluate the effects of such innovative sanitizers on the product end quality. For that reason, the present study intended to evaluate the effects of tannin extracts of Acacia mearnsii De Wild as alternatives to sodium hypochlorite as sanitizer of fresh cut lettuce leaves.

\section{MATERIALS AND METHODS}

Preparation of tannins extracts and chlorine solution

Two commercial samples containing tannin extracts of Acacia mearnsii De Wild., supplied by Tanac SA (Montenegro, RS) were used in the present study: Tanfloc $\mathrm{SG}^{\circledR}$ and Tanfloc $\mathrm{SM}^{\circledR}$, which consisted of a mixture of condensed polyphenols, mainly flavan-3-4-diol. Tanfloc is obtained via Mannich reaction of the tannin extract with an amine and an aldehyde molecule (MANGRICH et al., 2014). The main difference between Tanfloc SG and SM lies on $\mathrm{pH}$, wherein the first presents a range of 1.32.3 and the latter a range of 0.7-1.2. Tannin extracts (SM and SG) were diluted with distilled water at a concentration of $1 \%(\mathrm{v} / \mathrm{v})$.

Chlorine solution was prepared immediately before use by diluting $2.5 \%(\mathrm{v} / \mathrm{v})$ sodium hypochlorite (Anhembi, Brazil) in sterile water to achieve the concentration of $200 \mathrm{mg} \cdot \mathrm{L}^{-1}$ and the $\mathrm{pH}$ was adjusted to $\mathrm{pH} 6.5$ by adding citric acid. The concentration was verified with tests strips (Ecolab, USA).

Preparation of lettuce samples

Crisp leaf lettuce heads were obtained from a grower located in the rural area of Viamão, RS. Lettuce at horticultural maturity were harvested manually in the early hours of the day and transported in plastic boxes by car to the Laboratorio de Compostos Bioativos of the Universidade Federal do Rio Grande do Sul (UFRGS). Before processing, the raw material was kept under refrigeration at $10 \pm 2^{\circ} \mathrm{C}$ for a maximum of $2 \mathrm{~h}$.

Treatment procedure

After reception, a selection was carried out to remove the product with mechanical injury and decay incidence, followed by the toilet operation in which the external and dirty leaves were withdrawn together with the lettuce heart. About $2 \mathrm{~kg}$ of leaves free from defects were selected for each treatment, and were washed with tap water for 1 minute. Afterwards, they were sanitized with the following treatment solutions: T1) control - tap water washed for 1 minute; T2) immersion for 15 minutes in $200 \mathrm{mg}$ $\mathrm{L}^{-1}$ chlorine solution $(\mathrm{NaClO})$ plus 1 minute rinse in tap water at $7^{\circ} \mathrm{C}$; T3) immersion for 10 minutes in $1 \%(\mathrm{v} / \mathrm{v})$ of $\mathrm{SM}^{\circledR}$ tannin extract at $\mathrm{pH} 2.4$ plus 1 minute rinse in tap water at $7^{\circ} \mathrm{C}$; T4) immersion for 10 minutes in $1 \%(\mathrm{v} / \mathrm{v}) \mathrm{SG}^{\circledR}$ tannin extract at $\mathrm{pH} 2.6$ plus 1 minute rinse in tap water at $7^{\circ} \mathrm{C}$; T5) 10 minute immersion in $1 \%(\mathrm{v} / \mathrm{v}) \mathrm{SM}^{\circledR}$ tannin extract at $\mathrm{pH} 2.4$, without rinsing with tap water; and T6) immersion for 10 minutes in $1 \%(\mathrm{v} / \mathrm{v}) \mathrm{SG}^{\circledR}$ tannin extract at $\mathrm{pH} 2.6$ also without rinsing with tap water.

Samples were washed in chilled $\left(7^{\circ} \mathrm{C}\right)$ treatment solutions, using a $1 / 10$ ratio (weight of product/volume of solution). For tap water rinsing, it was used the same ratio weight/volume. After the last rinsing the samples were centrifuged at 690rpm for 5 minutes to remove excess of treatment solutions. Subsequently, $50 \mathrm{~g}$ of fresh-cut lettuce leaves were packed and sealed in $25 \mu \mathrm{m}$ polypropylene bags with oxygen $\left(\mathrm{O}_{2}\right)$ permeability of $7000 \mathrm{~cm}^{3} \mathrm{~m}^{-2} \mathrm{~d}^{-1}$, $\left(\mathrm{CO}_{2}\right)$ permeability of $20000 \mathrm{~cm}^{3} \mathrm{~m}^{-2} \mathrm{~d}^{-1}$ and water vapor permeability of $1 \mathrm{~g} \mathrm{~m}^{-2} \mathrm{~d}^{-1}$. The atmosphere inside the packages was modified and thermo sealed to an initial concentration of $5 \mathrm{kPa} \mathrm{O}_{2}, 15 \mathrm{kPa} \mathrm{CO}$ and nitrogen as balanced with a Fastvac F200 Flash thermo sealer. Samples were stored in a refrigerated displaying cabinet simulating retail settings. Quality evaluations were carried out on the day of 
experiment set up and after 5, 7 or 9 more days of storage at $3^{\circ} \mathrm{C}$ and 12 -hour light exposure.

Color measurement

A Konica/Minolta chromameter, model CR - 400 was used to determine the color of the lettuce leaves. Considering color variations among lettuce leaves within the same packages, 9 readings per experimental unit were taken to ensure data reliability. The averages of $\mathrm{L}^{*}, \mathrm{a}^{*}$ and $\mathrm{b}^{*}$ were used to determine the Total Color Difference $(\Delta \mathrm{E})$ according the following equation:

$(\Delta \mathrm{E})=\sqrt{ }\left(\mathrm{a}_{\mathrm{f}-}^{*} \mathrm{a}_{\mathrm{i}}^{*}\right)^{2}+\left(\mathrm{b}_{\mathrm{f}}^{*}-\mathrm{b}_{\mathrm{i}}^{*}\right)^{2}+\left(\mathrm{L}_{\mathrm{f}}^{*}-\mathrm{L}_{\mathrm{i}}^{*}\right)^{2}$

where $\mathrm{L}^{*}$ is the $\mathrm{L}^{*}$ value at the day of the experimental set up and $\mathrm{L}_{\mathrm{f}}^{*}$ the value of $\mathrm{L}^{*}$ at retrieval from storage at either 5,7 or 9 days. Likewise befalls for $a^{*} a_{f}^{*} b^{*}$ and $b_{f}^{*}$. The total color differences were ranked as ranging from small differences to very obvious color differences as indicated by GOYENECHE et al. (2014).

Microbiological analysis

Levels of total count of mesophilic microorganisms, total coliforms and Escherichia coli were determined in accordance with U.S. FDA (2001) and PIRES et al. (2011).

Statistical analysis

Three replicates of each treatment and for each analysis period were prepared and the average of each day/treatment/variable were analyzed as completely randomized blocks using the Statistical Analysis System Enterprise Guide 6.1, model ProcMixed. Averages were compared by Tukey test to determine differences at $\alpha=0.05$.

\section{RESULTS AND DISCUSSION}

Total color difference

According to the classification proposed by CHEN \& MAJUMDAR (2008), the color differences observed in fresh cut crisp lettuce during the nine days of refrigerated storage vary from appreciable color differences (values ranging from 3.1 to 6.0 ) to large differences color (values ranging from 6.1 up to 12.0). Lettuce leaves treated with the tannin extract $\mathrm{SM}^{\circledR}$ (T3) and followed by leaf rinsing were ranked at the end of the experiment as of appreciable color differences (Figure 1). Lettuce treated either with sodium hypochlorite (T2) or with the tannin extracts $\mathrm{SM}^{\circledR}$ (T3) or $\mathrm{SG}^{\circledR}$ (T4) presented color changes up to the last day of storage categorized as presenting appreciable color differences. Lettuce treated either with only tap water (T1) or with the tannin extracts $\mathrm{SM}^{\circledR}$ (T5) or $\mathrm{SG}^{\circledR}$ (T6) without subsequent rinsing were categorized as presenting large differences of color. Treatments in which the tannin extracts were not rinsed off after treatment application, color changes were categorized as large differences. That situation suggested that the tannin extracts do negatively influence tissue color. Consequently rinsing is a recommended procedure.

As to what is the main cause of that effect of tannins on tissue color there are some indications. The $\mathrm{pH}$ of the tannin solutions is in the range of 2.5 , a circumstance that possibly affects tissue metabolism both at cell walls and internally at the level of organelles, such as the chloroplasts. Chlorophyll breakdown that eventually leads to colorless products results from the reduction of chlorophyll molecules to chlorophyllides prompted by chlorophyllases activity. Chlorophyllides are then converted to pheophorbide via magnesium dechelatase (HEATON \& MARANGONI, 1996). When low $\mathrm{pH}$ coatings such as tannin extracts are applied, the low pH mediates the loss of the magnesium ion from the chlorophyll molecules in the absence of dechelatase activity. Low $\mathrm{pH}$ might also inactivate chlorophyll degrading enzymes which have a optimum $\mathrm{pH}$ with about 7.0 (SUZUKI et al., 2002; ARKUS et al., 2005) and for that reason changes in lettuce leaf color results in pheophytin accumulation yielding an olive-brown color (HEATON \& MARANGONI, 1996).

\section{Microbiological analysis}

The presence of $\boldsymbol{E}$. coli on minimally processed lettuce leaves was always below the detection limits $\left(1 \log \mathrm{cfu} \mathrm{g}^{-1}\right)$ after 9 days of storage independently of the applied sanitizer. The initial mesophilic load on the unwashed lettuce leaves was in between 6 to $7 \log \mathrm{cfu} \mathrm{g}^{-1}$. These levels were in the expected range for fresh-cut produce (NGUYENTHE \& CARLIN, 1994). OLIVEIRA et al. (2010) concluded that mesophilic bacteria are in the range of $10^{3}$ to $10^{9} \mathrm{CFUg}^{-1}$ in raw vegetables after harvest, depending on the crop and the growing conditions.

In the present research a decrease of about 1.86 to $4.41 \log \mathrm{cfu} \mathrm{g}^{-1}$ in total counts of mesophilic cells amongst treated samples and the initial load at day 0 was determined (Figure 2). The highest initial reduction of $4.4 \log \mathrm{cfu} \mathrm{g}^{-1}$ was observed when the tannin extract $\mathrm{SM}^{\circledR}$ was used to wash the lettuce leaves. Washing lettuce with only tap water (control treatment) resulted in the lowest reduction of mesophilic counts. The T2 and T3 treatments successfully suppressed bacterial growth in the first 


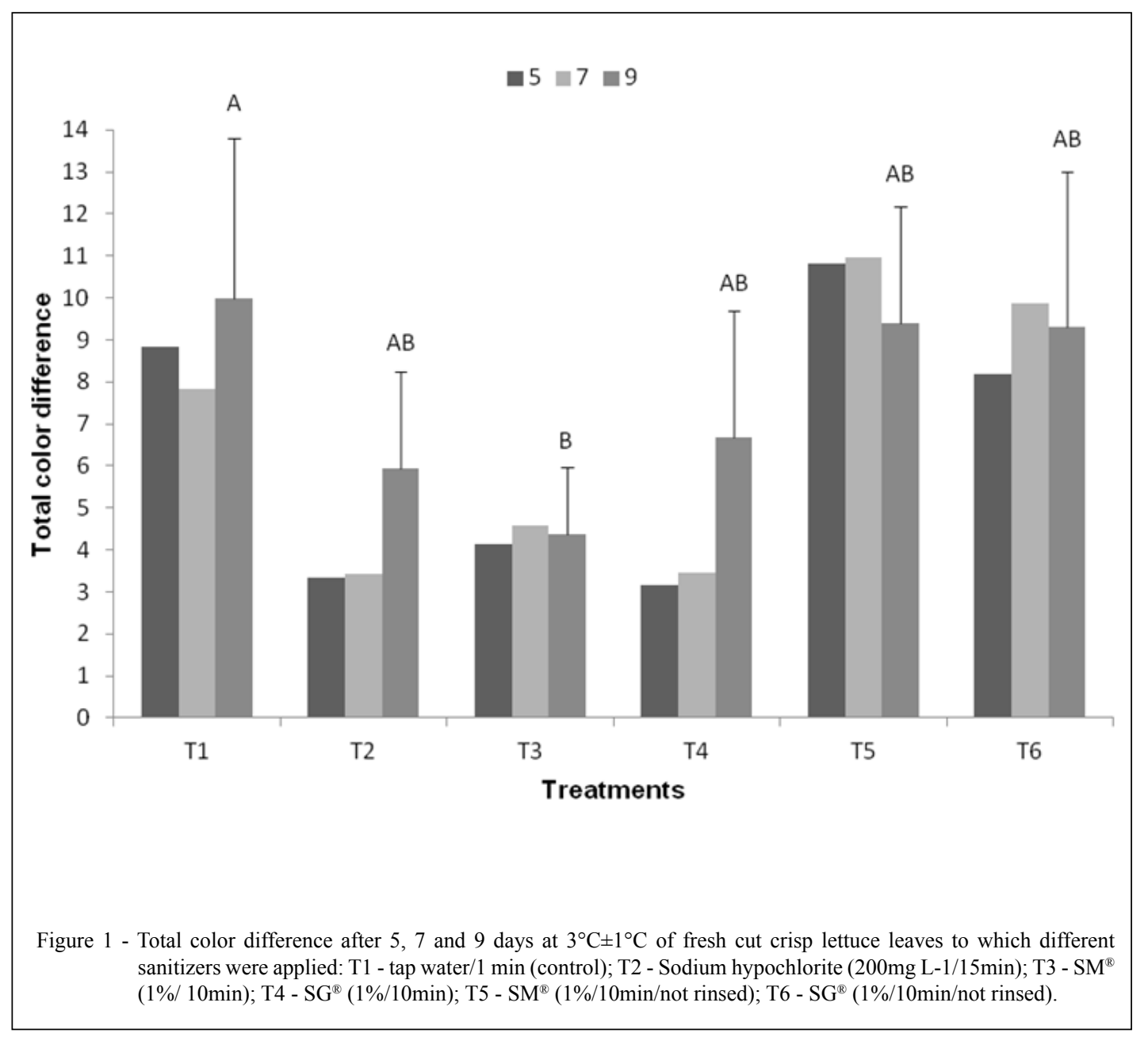

5 days of storage, showing significantly different results from other treatments at day $5(\mathrm{P}<0.05)$. It was observed an increase in mesophilic counts in the first 5 days of storage, followed by the decrease after 7 days of storage for T5 and T6 treatments. This phenomenon can be a residual effect of the tannin extracts, since T5 and T6 treatments are not rinsed with water, but the tendency of all treatments did not present significant differences after 9 days of storage.

The initial count of total coliforms was in the range of 4 and $5 \log$ cfu $^{-1}$. Immediately after washing with the sanitizers, total coliforms also presented a reduction in all treatments in colony forming units. The highest reduction of $4.47 \mathrm{log}$ was observed when the T4 treatment was applied as sanitizer (Figure 3). Final counts of total coliforms after 9 days of storage were between 2.6 and $4.5310 \mathrm{l}$ $\mathrm{cfu} \mathrm{g}^{-1}$. In relation to total coliform counts, BERBARI et al. (2001) concluded that a population of total coliforms of about $10^{5}(5 \log )$ as the most probable number $\mathrm{g}^{-1}$ of coliforms corresponded to high contamination levels of these microorganisms in the product. Data from the present experiments did not exceed $10^{5}$ (5 log cycles) (Figure 3$)$.

It is important to consider that regardless of the initial reduction achieved after the treatments, microbial populations of total counts of mesophilic bacteria and total coliforms increased gradually during storage time (Figures 2 and 3). That occurrence has been previously described by several authors, who suggested that microbial populations of ready to eat vegetables could increase faster and even reach an equal or higher number after disinfection (ARTÉS-HERNÁNDEZ et al., 2009; GÓMEZ-LÓPEZ et al., 2013). Also in accordance to the data gathered in the present study, ALLENDE et al. (2008) observed that bacterial count at the end of storage was similar to the count observed when 


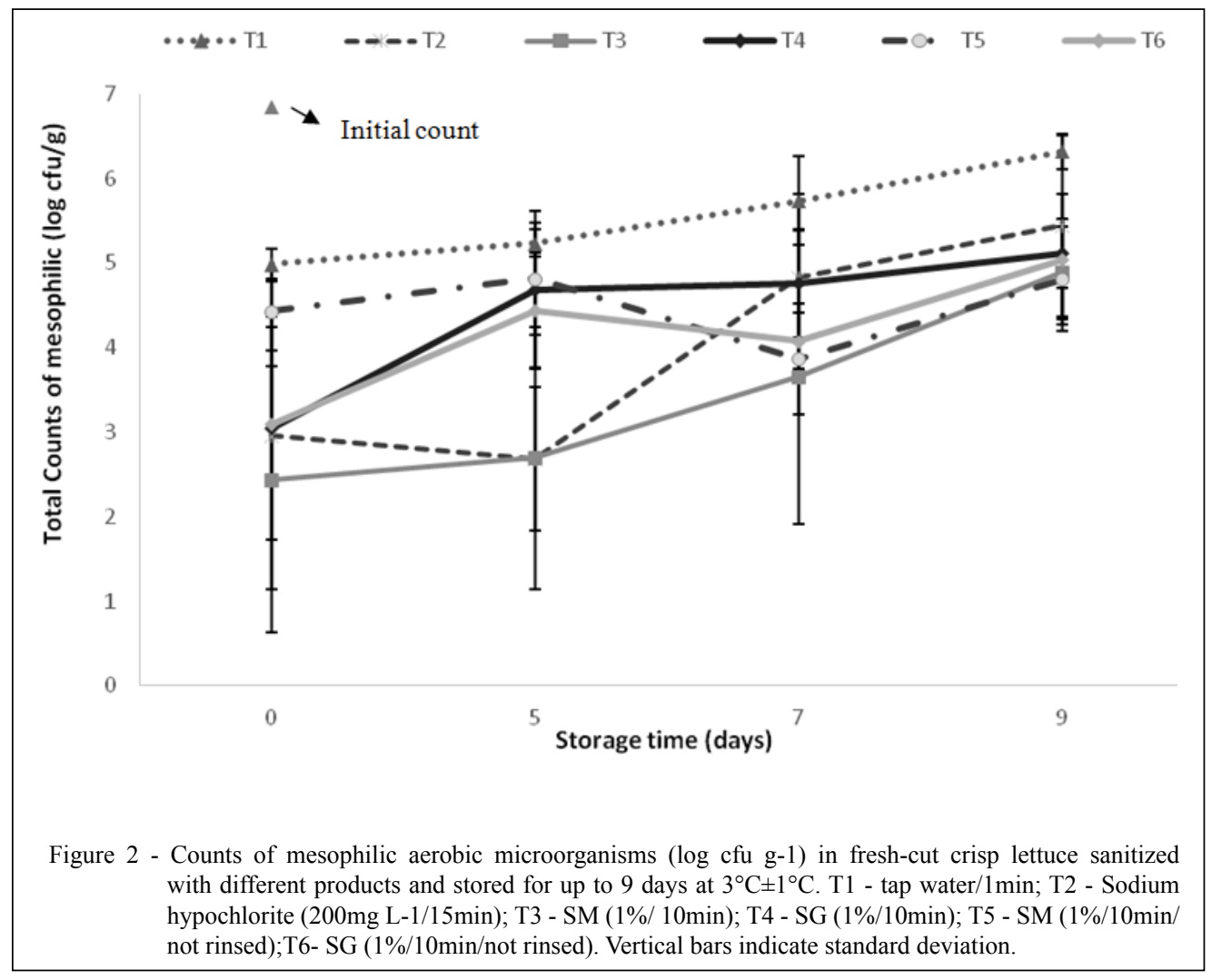

the product was washed with tap water or with sanitizing solutions.

It is also conceivable that tannin extracts are not appropriate for shelf-life extension of minimally processed crisp leaf lettuce as they yielded after nine days of storage similar results to those of tap water washing. Nonetheless, tannin extracts could be used in washing waters to avoid cross-contamination throughout lettuce processing as already observed by ALLENDE et al. (2008) considering that these tannin extracts presented high initial reductions in the populations of mesophylls and total coliforms and in addition did not affect the quality of the product.

The microbiological hygiene quality achieved using sodium hypochlorite circumscribed to the total count of mesophilic cells, total coliforms and E. coli was not superior to the sanitation presented by the lettuce samples sanitized by the tannin extract $\mathrm{SM}^{\circledR}$. That evidence is accreditable to the condition that the tannin extract $\mathrm{SM}^{\circledR}$ is concocted by Mannich reaction rendering this extract bonded to a quaternary ammonium compound. Quaternary ammonium compounds are reported to have antibacterial properties (MCEGAN
\& DANYYLU, 2015). Furthermore, the low $\mathrm{pH}$ of the $\mathrm{SM}^{\circledR}$ extract might be part of that antibacterial action.

\section{CONCLUSION}

Microbiological and quality analyses indicate that the application of the tannin extract $\mathrm{SM}^{\circledR}$ (T3) results is similar to hypochlorite treatment results (T2). Nonetheless, $\mathrm{SM}^{\circledR}$ (T3) does not ameliorate shelf life in comparison to the use of tap water (T1) on minimally processed crisp leaf lettuce stored under modified atmosphere. Tannin extracts might turn out to be alternatives to chlorine as sanitizing media in view of the fact that they are rather inexpensive, easily formulated and do not give off potential carcinogenic residues. Therefore, the tannin extract $\mathrm{SM}^{\circledR}$ (T3) could be used in washing water to reduce the initial microbiological load as to avoid cross contamination in minimally processing of vegetables. The lack of knowledge on harmfulness of tannins after continuous intake compels further studies to ascertain the appropriateness of this natural extract for fresh-cut produce sanitization. 


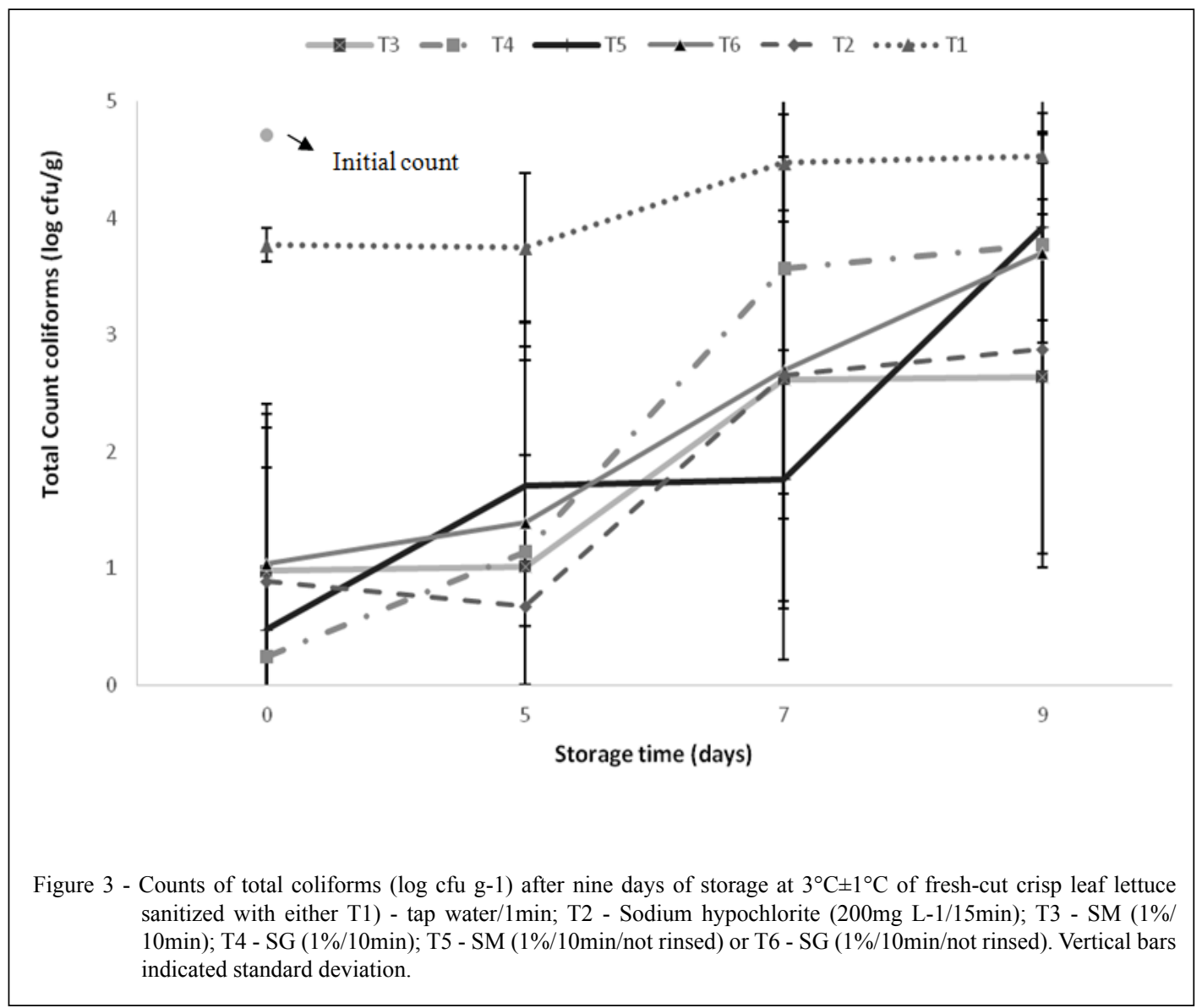

\section{ACKNOWLEDGMENTS}

The authors express gratitude to the Conselho Nacional de Desenvolvimento Científico e Tecnológico (CNPq) for financial support.

\section{REFERENCES}

ANDERSON, M. et al. Pathogen-produce pair attribution risk ranking tool to prioritize fresh produce commodity and pathogen combinations for further evaluation ( $\left.\mathrm{P}^{3} \mathrm{ARRT}\right)$. Food Control, v.22, p.1865-1872, 2011. Available from: <http:/www.sciencedirect. com/science/article/pii/S0956713511001769>. Accessed: nov. 05, 2015. doi: 10.1016/j.foodcont.2011.04.028.

ALLENDE, A. et al. Role of comercial sanitizers and washing systems on epiphytic microorganisms and sensory quality of fresh cut escarole and lettuce. Postharvest Biology and Technology, v.49, p.155-163, 2008. Available from: <http://www.sciencedirect. com/science/article/pii/S0925521408000094>. Accessed: dec. 15 , 2015. doi: $10.1016 /$ j.postharvbio.2007.12.010

ARKUS, K.A.J. et al. Mechanistic analysis of wheat chlorophyllase. Archives of Biochemistry and Biophysics, v.438, p.146-155, 2005. Available from: <http://www.sciencedirect.com/science/ article/pii/S0003986105001700>. Accessed: set. 20, 2015. doi: 10.1016/j.abb.2005.04.019.
ARTÉS-HERNÁNDEZ, F. et al. Effect of UV-C radiation on quality of minimally processed spinach leaves. Journal of the Science of Food and Agriculture, v.89, p.414-421, 2009. Available from: <http://onlinelibrary.wiley.com/doi/10.1002/jsfa.3460/epdf>. Accessed: set. 21, 2015. doi: 10.1002/jsfa.3460.

ARTÉS, F.; ALLENDE, A. Processing lines and alternative preservation techniques to prolong the shelf-life of minimally fresh processed leafy vegetables. European Journal of Horticultural Science, v.70, n.5, p.231-245, 2005. Available from: <http://www.pubhort.org/ejhs/2005/34006.htm>. Accessed: oct. 3, 2014.

ARIAS, M.E. et al. Antibacterial activity of ethanolic and aqueous extracts of Acacia aromaGill. ex Hook et Arn. Life Sciences, v.75, p.191-202, 2004. Available from: <http://www.sciencedirect. com/science/article/pii/S002432050400222X>. Accessed: set. 05, 2014. doi: 10.1016/j.1fs.2003.12.007.

BERBARI, S.A.G. et al. Effect of chlorine in the wash water for disinfecting minimally processed lettuce. Food Science and Technology, v.21, p.197-201, 2001. Available from: $<$ http://www.scielo.br/scielo.php?script=sci_arttext\&pid $=$ S0101-20612001000200014 $>$. Accessed: jan. 25, 2014. doi: 10.1590/S0101-20612001000200014.

CHEN, X.D.; MAJUMDAR, A. Drying technologies in food processing. WestSussex: Wiley-Blackwell, 2008. 352p. 
CHUNG, K.T. et al. Tannins and human health: a review. Critical Reviews in Food Science and Nutrition, v.38, p.421-464, 2008. Available from: <http://www.ncbi.nlm.nih.gov/pubmed/9759559>. Accessed: fev. 5, 2015. doi: 10.1080/1040869989127427.

HEATON, J.W.; MARANGONI, A.G. Chlorophyll degradation in processed foods and senescent plant tissues. Trends Food Science and Technology, v.7, p.8-15, 1996. Available from: <http:// www.sciencedirect.com/science/article/pii/0924224496813525>. Accessed: jan. 19, 2015. doi: 10.1016/0924-2244(96)81352-5.

HERNÁNDEZ, N.N.R. et al. Actividad antimicrobiana de Waltheria indoca y Acacia farnesiana. Revista CENIC Ciências Biológicas, v.40, n.2, p.129-134, 2009. Available from: <http:// www.redalyc.org/articulo.oa?id=181221568008>. Accessed: jan. $19,2015$.

GÓMEZ-LÓPEZ, V.M. et al. Generation of trihalomethanes with chlorine-based sanitizers and impact on microbial, nutritional and sensory quality of baby spinach. Postharvest Biology and Technology, v.85, p.210-217, 2013. Available from: <http://www. sciencedirect.com/science/article/pii/S0925521413001543>. Accessed: jan. 19, 2015. doi: 10.1016/j.postharvbio.2013.05.012.

MANGRICH, A.S. et al. Green chemistry in water treatment: coagulant derived from use of Acacia mearnsii tannin. Revista Virtual de Quimica, v.6, n.1, p.2-15, 2014. Available from: $<$ http://rvq.sbq.org.br/index.php/rvq/article/view/425>. Accessed dec. 2, 2014. doi: 10.5935/1984-6835.20140002.

MCEGAN, M.; DANYYLU, M.D. Evaluation of aqueous and alcohol-based quaternary ammonium sanitizers for inactivating Salmonella spp., Escherichia coli O157:H7, and Listeria monocytogenes on peanut and pistachio shells. Food Microbiololy, v.47, p.93-98, 2015.Available from: <http://www. sciencedirect.com/science/article/pii/S0740002014002858>. Accessed: nov. 24, 2014. doi: 10.1016/j.fm.2014.11.010.

NGUYEN-THE, C.; CARLIN, F. The microbiology of minimally processed fresh fruits and vegetables. Critical Reviews in Food Science and Nutrition, v.34, p.371-401, 1994. Available from: <http://www.tandfonline.com/doi/ pdf/10.1080/10408399409527668>. Accessed: dec. 2, 2014. doi: $10.1080 / 10408399409527668$

OLIVEIRA, M. et al. Microbiological quality of fresh lettuce from organic and conventional production. Food Microbiology, v.27, n.5, p.679-684, 2010. Available from: <http://www.sciencedirect. com/science/article/pii/S074000201000050X>. Accessed: oct. 2, 2014. doi: 10.1016/j.fm.2010.03.008.

ÖLMEZ, H.; KRETZSCHMAR, U. Potential alternative methods for organic fresh-cut industry for minimizing water consumption and environmental impact. LWT Food Science and Technology, v.42, p.686-693, 2009. Available from: <http://www.sciencedirect.com/science/article/ pii/S0023643808001862>. Accessed: set. 12, 2014. doi: 10.1016/j.lwt.2008.08.001.

PIRES, D. et al. Use of newly isolated phages for control of Pseudomonas aeruginosa PAO1 and ATCC 10145 biofilms. Research in Microbiology, v.162, n.8, p.798-806, 2011. Available from: $<$ http://www.sciencedirect.com/science/article/pii/ S092325081100115X>. Accessed: set. 12, 2014. doi: 10.1016/j. resmic.2011.06.010.

SALA, F.C.; COSTA, C.P. Retrospective and trends of Brazilian lettuce crop. Horticultura Brasileira, v.30, p.187-194, 2012. Available from: <http://www.scielo.br/scielo.php?script=sci_artt ext\&pid=S0102-05362012000200002>. Accessed: jan. 12, 2015. doi: $10.1590 / \mathrm{S} 0102-05362012000200002$

SÃO JOSÉ, J.F.B. et al. Decontamination by ultrasound application in fresh fruits and vegetables. Food Control, v.45, p.36-50, 2014. Available from: $<$ http://www.sciencedirect.com/science/article/pii/ S0956713514001984>. Accessed: jan. 24, 2015. doi: 10.1016/j. foodcont.2014.04.015.

SUZUKI, Y. et al. Two enzymatic reaction pathways in the formation of pyropheophorbide a. Photosynthesis Research, v.74, p.225-233, 2002. Available from: <http://link.springer.com/articl e/10.1023\%2FA\%3A1020919929608>. Accessed: fev. 14, 2015. doi: 10.1023/A:1020919929608.

U.S. FDA. (2001). Bacteriological analytical manual online. Available from: $<$ http://www.fda.gov/Food/FoodScienceResearch/ LaboratoryMethods/ucm2006949.htm>. Acessed: fev. 2, 2015.

VORAVUTHIKUNCHAI, S. et al. Effective medicinal plants against enterohaemorrhagic Escherichia coli O157:H7. Journal of Ethnopharmacology, v.94, n.1, p.49-54, 2004. Available from: <http://www.sciencedirect.com/science/article/pii/ S0378874104001606>. Accessed: fev. 14, 2015. doi: 10.1016/j. jep.2004.03.036. 